\title{
Impact of highly active antiretroviral therapy on hematological indices among HIV-1 infected children at Kenyatta National Hospital-Kenya: retrospective study
}

\author{
Elizabeth Gathoni Kibaru ${ }^{1,4^{*}}$, Ruth Nduati ${ }^{2}$, Dalton Wamalwa ${ }^{2}$ and Nyambura Kariuki ${ }^{2,3}$
}

\begin{abstract}
Background: HIV infected children experience a range of hematological complications which show marked improvement within 6 months of initiating anti-retroviral therapy. The Objectives of the study was to describe the changes in hematological indices of HIV-1 infected children following 6 months of treatment with first line antiretroviral drugs (ARVs) regimen.
\end{abstract}

Methods: A retrospective study was conducted between September and November 2008. During this period medical records of children attending Comprehensive Care Clinic at Kenyatta National hospital were reviewed daily. HIV infected children aged 5-144 months were enrolled if they had received antiretroviral drugs for at least 6 months with available and complete laboratory results.

Results: Medical records of 337 children meeting enrollment criteria were included in the study. The median age was 63 months with equal male to female ratio. Following 6 months of HAART, prevalence of anemia (Hemoglobin ( $\mathrm{Hb}$ ) $<10 \mathrm{~g} / \mathrm{dl}$ ) declined significantly from 35.9 to $16.6 \%$ a nearly $50 \%$ reduction in the risk of anemia RR $=0.56[(95 \% \mathrm{Cl}$ $0.44,0.70) p<0.001]$. There was significant increase in $\mathrm{Hb}$, mean corpuscular volume (MCV), mean corpuscular hemoglobin $(\mathrm{MCH})$ and platelets above the baseline measurements $(\mathrm{p}<0.0001)$ and a significant decline in total white blood cell counts $>11,000$ cell/ $/ \mathrm{mm}^{3}$ but a none significant decrease in red blood cells (RBC). Pre-HAART, World Health Organization (WHO) stage 3 and 4 was associated with a ten-fold increased likelihood of anemia. Chronic malnutrition was associated with anemia but not wasting and immunologic staging of disease.

Conclusion: Hematological abnormalities changed significantly within 6 months of antiretroviral therapy with significant increase in hemoglobin level, MCV, MCH and platelet and decrease in WBC and RBC.

Keywords: Paediatric HIV infection, Hematological abnormalities, Changes of hematological parameters

\section{Background}

Hematological complications of human deficiency virus infection (HIV) which include cytopenias of all major cell lines were recognized shortly after the first description of AIDS cases [1]. Unexplained anemia defined as hemoglobin of less than $8 \mathrm{~g} / \mathrm{dl}$, neutropenia $<1000 \mathrm{cells} / \mathrm{mm}^{3}$ or thrombocytopenia less than 30,000 platelets $/ \mathrm{mm}^{3}$

\footnotetext{
*Correspondence: gathonigakinya@yahoo.com

${ }^{4}$ P.O. Box 2275-20100, Nakuru, Kenya

Full list of author information is available at the end of the article
}

persisting for more than one month are currently classified as WHO stage 3 disease [2]. Anemia, the most common abnormality causes chronic fatigue, affects cognitive function and influences the choice of ART and opportunistic infection (OI) medications and has been noted to be the commonest hematological abnormalities in adults in Kenya [3, 4].

In published literature prevalence of anemia among HIV-1 infected children varies from 16 to $94 \%$ and this increases with advancing stage of HIV disease but varies with sex, age and the definition of anemia used [5-10]. 
In a meta-analysis of over 2000 HIV infected children, the prevalence of mild [hemoglobin ( $\mathrm{Hb}$ ) 10-12.0] and moderate anemia ( $\mathrm{Hb} 8.0-9.9)$ was $22-94 \%$ and 3-82\% respectively [10]. The prevalence of mild and moderate anemia in Western settings ranged from 22 to $94 \%$ and 11 to $82 \%$ respectively while in tropical settings it was 50-91 \% for mild anemia and 3-38 \% for moderate anemia [10]. Neutropenia is present in approximately $10 \%$ of patients with early, asymptomatic HIV infection, and more than half in individuals with more advanced HIVrelated immunodeficiency $[5,6,11]$. Thrombocytopenia which is frequently asymptomatic occurs in $20 \%$ to $33 \%$ of paediatric patients with HIV with the prevalence increasing with duration of illness and development of Aids $[5,6,9,11,12]$.

The most important cause of anemia in HIV infected children is insufficient production of erythrocytes caused by ineffective erythropoiesis, reduced erythropoietin production, associated infections, neoplasia, medications and micronutrient deficiencies. Iron deficiency is the most common cause of nutritional anemia globally. There is significant geographical overlap of areas of the world where iron deficiency anemia (IDA) and paediatric HIV are distributed. The causes of anemia in the community investigated are Multifactorial with iron deficiency prevalence being high due to nutritional deficiency and helminthes. In a study in western Kenya by Footer et al. anemia was found to be prevalent and was present in $71.8 \%$ of children [13]. Factors commonly thought to be associated with anemia were found to be widespread, including malaria parasitemia (32.5\%), iron deficiency (34.6\%), vitamin A deficiency (16.3\%), stunting (29.6\%), wasting (3.3\%), $\mathrm{HbS}(17.1 \%)$, HbSS (1.6\%), heterozygous $\alpha$-thalassemia (38.5\%), and homozygous $\alpha$-thalassemia (9.6 \%) [13]. This is similar to WHO finding that Iron deficiency is the most common cause of anemia of micronutrient-related etiology worldwide, affecting about $50 \%$ of women and children in developing countries and about $25 \%$ of men [14]. Another prominent cause of reduced production of all hematological elements in patients with HIV infection is the common use of multiple medications, many of which may cause marrow suppression e.g. Zidovudine (AZT) and other nucleoside analogues can cause a dose-dependent neutropenia [15]. Other medications causing hematological abnormalities include ganciclovir, trimethoprim-sulphamethoxazole, pentamidine and dapsone [9].

Studies have confirmed the ability of HAART to correct or improve the anemia and other hematological parameters of HIV infection. In a study of 6725 HIV-infected patients from across Europe, Microft and colleagues found that the use of Stavudine, zidovudine and Lamivudine was statistically associated with improvement in hemoglobin levels [16]. When used for longer periods of time, HAART was associated with greater likelihood of correcting anemia. Microft et al. found that, $65.5 \%$ of patients were anemic before the use of HAART, $53 \%$ were anemic after 6 months of HAART $(\mathrm{p}<0.0001)$, and $46 \%$ were anemic after 12 months of HAART [16]. Huang et al. found an increase in $\mathrm{Hb}$ occurring with mean increase from baseline of 13.9 to $14.1 \mathrm{~g} / \mathrm{dl}$ after 3 months of treatment and this was not statistically significant [17]. After 6 months $\mathrm{Hb}$ had increased to $14.6 \mathrm{~g} / \mathrm{dl}(\mathrm{p}<0.01)$, 9 months $14.6 \mathrm{~g} / \mathrm{dl}(\mathrm{p}=0.001)$ and at 12 months mean of $14.3 \mathrm{~g} / \mathrm{dl}(\mathrm{p}<0.01)$ [17]. In a different study in children in Zambia, the mean hemoglobin increased from $10.3 \mathrm{~g} /$ $\mathrm{dl}$ at baseline to a mean of $11.3 \mathrm{~g} / \mathrm{dl}$ (CI $95 \% 11.2-11.4 \mathrm{~g} /$ dl) after 6 months of HAART [18]. In a study in BurkinaFaso hematological changes after 6 months of AZT based HAART showed anemia at 51.4 vs $80.3 \%$ at baseline with $\mathrm{P}=0.0001$ [19]. Other hematological parameter noted to markedly increase after HAART was MCV. Huang et al. found an increase of MCV following treatment from baseline of 5.5 to $98.9 \mathrm{fl} \mathrm{p}<0.1$ at 3 months, $105.5 \mathrm{fl}$ (p < 0.001) at 6 months, $106 \mathrm{fl}$ at 9 months $(\mathrm{p}<0.001)$ and $102.8 \mathrm{fl} \mathrm{p}<0.001$ at 12 months [17].

The prevalence of hematological abnormalities among children treated with ART in routine care settings in Kenya have not yet been described even though the first line antiretroviral regimen to date includes drugs with significant hematological adverse events such as zidovudine. The objective of the study was to describe the changes in hemoglobin levels, red cell morphology, white blood cells and platelets in HIV-1 infected children aged $5-144$ months following 6 months of highly active antiretroviral therapy at the comprehensive care clinic of $\mathrm{KNH}$.

\section{Results}

Baseline characteristics of the study participants

A total of 337 children were recruited into the study, among them $53.4 \%$ female and $46.6 \%$ male giving a female to male ratio of 1.1:1, and a median age of 63 months (range of 5-144 months) as shown in the Table 1. Almost all children in the study population received Cotrimoxazole $323(98.8 \%)$ and the remaining 4 (1.2\%) received dapsone. One eighty nine $(56.4 \%)$ presented in WHO clinical stage III at ART initiation while $48(14.3 \%)$ were in WHO clinical stage IV. The number/ proportion of children in stages I and II were 77 (23\%) and $21(6.3 \%)$ respectively. Eighty four children (25\%) were started on iron supplements during the initiation of antiretroviral drugs. Zidovudine-Lamivudine backbone (AZT/3TC) based regimens were the most frequently used first line ART protocol and used by 291 (86.3\%) children in combination with efavirenz (EFV), nevirapine (NVP) or abacavir (ABC). 
Table 1 Baseline demographic characteristics of the study participants

\begin{tabular}{ll}
\hline Variable & $\begin{array}{c}\text { Frequency }(n=337) \text { number, } \\
(\%), \text { or median }\end{array}$ \\
Female & $179(53.4 \%)$ \\
Male & $156(46.6 \%)$ \\
Age (months) & \\
Median & 63 \\
IQR & $36-97$ \\
Weight for age Z score & \\
SD $>-2$ & $130(39 \%)$ \\
SD -3 to -2 & $95(28 \%)$ \\
SD $<-3$ & $112(33 \%)$ \\
Weight for height Z score & \\
SD $>-2$ & $229(88 \%)$ \\
SD -3 to -2 & $22(6.5 \%)$ \\
SD $<-3$ & $15(4.4 \%)$ \\
Height for age Z score & \\
SD $>-2$ & $85(25 \%)$ \\
SD -3 to -2 & $53(16 \%)$ \\
SD $<-3$ & $198(59 \%)$ \\
CD4 count median (1QR) & $456(171.0-753)$ \\
CD4 percent median (1QR) & $9.9(5.0-14.0)$ \\
\hline
\end{tabular}

Hematological parameters pre and six months post HAART initiation

\section{Hemoglobin level}

At baseline $35.9 \%$ study participants had a $\mathrm{Hb}<10.0 \mathrm{~g} / \mathrm{dl}$ compared to $16.6 \%$ after 6 months of ART, a statistically significant reduction in risk of anemia $\mathrm{RR}=0.56[(95 \%$
CI $0.44,077) \mathrm{p}<0.0001$ ] as shown in Table 2. The median $\mathrm{Hb}$ at baseline was 10.6 and $11.5 \mathrm{~g} / \mathrm{dl}$ before and after 6 months of ART, a significant median increase in $\mathrm{Hb}$ of $0.9 \mathrm{~g} / \mathrm{dl}(\mathrm{p}<0.0001)$ as shown in Table 3 . The median $\mathrm{Hb}$ level of 203 (75\%) children who were not on iron supplements at baseline and after 6 months of ART was $11 \mathrm{~g} / \mathrm{dl}$, and $11.8 \mathrm{~g} / \mathrm{dl}$ respectively a statistical significant change $(\mathrm{p}<0.0001)$. Eighty four children $(25 \%)$ who were receiving iron supplements had a baseline median $\mathrm{Hb}$ of $9.25 \mathrm{~g} / \mathrm{dl}$ and increased to $11 \mathrm{~g} / \mathrm{dl}$ following 6 months of treatment, a significant median increase of $\mathrm{Hb} 1.75 \mathrm{~g} / \mathrm{dl}$ $(\mathrm{p}<0.0001)$. Female were reported to have higher hemoglobin levels at the baseline $51.9 \%$ compared to the males $40.3 \%$ although there were more males with moderate anemia (37\%) compared to female $23.1 \%$. Following 6 months of HAART majority of children of both sexes had hemoglobin levels within the normal ranges with $73.7 \%$ being female and $68.5 \%$ males. Children who initially were reported with severe anemia had reduced to $1.3 \%$ from $4.5 \%$ of female with no male reported to have severe anemia.

\section{Mean corpuscular volume (MCV)}

At baseline $31 \%$ of the study participants had a mean corpuscular volume (MCV) below the $70 \mathrm{fl}$ compared to $8.3 \%$ at end of 6 months of ART treatment, a $63 \%$ decline in the risk $\mathrm{RR}=0.37$ [(95\% CI 0.27,0.52) $\mathrm{P}<0.0001]$ as shown in Table 2 . The median corpuscular volume at baseline was $75.9 \mathrm{fl}$ and increased to $89.2 \mathrm{fl}$ after 6 months of HAART, a statistically significant median increase by $13.2 \mathrm{fl}$ of corpuscular volume $(\mathrm{p}<0.0001)$ as show in Table 3.

Table 2 Changes in the prevalence of abnormal haematological parameters

\begin{tabular}{|c|c|c|c|c|}
\hline Characteristic N = 337 & Baseline no (\%) & $\begin{array}{l}6 \text { months after initiation } \\
\text { of HAART no (\%) }\end{array}$ & Relative risk (95 \% Cl) & $P$ value \\
\hline $\mathrm{Hb}<10 \mathrm{~g} / \mathrm{dl}$ & $121(35.9)$ & $56(16.6)$ & $0.56(0.44,0.70)$ & $<0.0001$ \\
\hline$M C V<70$ fl & $104(31.0)$ & $28(8.3)$ & $0.37(0.27,0.52)$ & $<0.0001$ \\
\hline $\mathrm{MCH}<24 \mathrm{pg}$ & $154(46.7)$ & 49 (14.6) & $0.45(0.35,0.59)$ & $<0.0001$ \\
\hline Platelets $<150,000$ & $67(20.0)$ & $22(6.5)$ & $0.46(0.32,0.66)$ & $<0.0001$ \\
\hline WBC $<11,000$ & $33(10.0)$ & $21(6.2)$ & $0.76(0.54,1.08)$ & 0.09 \\
\hline Granulocytes $<1000$ & $22(6.5)$ & $52(16)$ & $1.48(1.25,1.75)$ & $<0.0001$ \\
\hline
\end{tabular}

Table 3 Changes in haemoglobin levels, MCV, MCH and RBC

\begin{tabular}{|c|c|c|c|c|}
\hline Characteristic $\mathrm{N}=337$ & Baseline median no (\%) or (IQR) & $\begin{array}{l}6 \text { months after initiation } \\
\text { of HAART no (IQR) }\end{array}$ & Median change & P value \\
\hline $\mathrm{Hb}(\mathrm{g} / \mathrm{dl})$ & $10.6(9.4-11.6)$ & $11.5(10.5-12.4)$ & 0.9 & $<0.0001$ \\
\hline$M C V(f l)$ & $75.9(68.0-82.3)$ & $89.2(80.0-97.6)$ & 13.2 & $<0.0001$ \\
\hline $\mathrm{MCH}(\mathrm{pg})$ & $24.3(21.5-27.5)$ & $29.1(25.8-32.1)$ & 4.9 & $<0.0001$ \\
\hline $\mathrm{RBC}\left(\mathrm{m} / \mathrm{mm}^{3}\right)$ & $4.3(3.8-5.0)$ & $4.0(3.6-4.3)$ & 0.3 & 0.27 \\
\hline
\end{tabular}


Table 4 Haemoglobin level changes and HAART combination

\begin{tabular}{|c|c|c|c|c|c|}
\hline Drug regimen & Number & $\begin{array}{l}\text { Mean } \mathrm{Hb} \text { at } \\
\text { baseline }\end{array}$ & $\begin{array}{l}\text { Mean } \mathrm{Hb} \text { after } \\
6 \text { months }\end{array}$ & Mean change & $P$ Value \\
\hline Zidovudine combination & 293 & 10.7 & 11.4 & 0.7 & 0.000 \\
\hline Stavudine combination & 38 & 9.77 & 11.6 & 1.83 & 0.01 \\
\hline Other combinations & 6 & 7.68 & 11.2 & 3.52 & 0.864 \\
\hline
\end{tabular}

\section{Mean corpuscular hemoglobin (MCH)}

The prevalence of low mean corpuscular hemoglobin $(\mathrm{MCH})$ before and after 6 months of ARVs was 46.7 and $14.6 \%$ respectively. The relative risk of low $\mathrm{MCH}$ was $\mathrm{RR}=0.45$ [(95\% CI 0.35, 0.59) p < 0.0001], a statistically significant reduction. At baseline median $\mathrm{MCH}$ was $24.3 \mathrm{pg}$ and increased to $29.0 \mathrm{pg}$ after 6 months of ART a statistically significant median increase of $4.9 \mathrm{pg}$ $(\mathrm{p}<0.0001)$ as shown in Table 3.

\section{Red blood cells}

At baseline the median number of red cells was 4.3 million $/ \mathrm{mm}^{3}$ and declined to 4.0 million $/ \mathrm{mm}^{3}$ after 6 months of highly active antiretroviral therapy. The median change in $\mathrm{RBC}$ was 0.4 million cells $/ \mathrm{mm}^{3}$ and this was not statistically significant $(\mathrm{p}=0.27)$ as shown in Table 3 .

\section{HAART regimen combination and hemoglobin level}

Children with Stavudine combination had higher hemoglobin increments as compared to zidovudine or other combinations as shown in Table 4. There was statistical significant increase in mean $\mathrm{Hb}$ level in both zidovudine and Stavudine combinations but the mean hemoglobin change was more with Stavudine combinations at $1.83 \mathrm{~g} /$ $\mathrm{dl}$ for Stavudine combination and $0.7 \mathrm{~g} / \mathrm{dl}$ for zidovudine combinations. Indications of choice of regimen to use were based on baseline hemoglobin levels. Majority of children with $\mathrm{Hb}$ of above10 g/dl were started on zidovudine combination while Children with low $\mathrm{Hb}$ of less than $10 \mathrm{~g} / \mathrm{dl}$ were started on Stavudine or other combinations.

\section{Platelets}

Proportion of children with platelet counts below $150,000 / \mathrm{mm} 3$ before and after 6 months of ARV was 20 and $6.5 \%$ respectively, a significant reduction in the risk of thrombocytopenia $\mathrm{RR}=0.46$ [(95\% CI 0.32, 0.66) $\mathrm{p}<0.0001$ ] as shown in Table 3. At baseline the median platelets counts were $255 \times 10^{3} / \mathrm{mm}^{3}$ (IQR $159 \times 10^{3} /$ $\mathrm{mm}^{3}-352 \times 10^{3} / \mathrm{mm}^{3}$ ), and which increased to a median of $279 \times 10^{3} / \mathrm{mm}^{3}$ (IQR $224 \times 10^{3} / \mathrm{mm}^{3}-349 \times 10^{3} /$ $\mathrm{mm}^{3}$ ) following 6 months of ART as shown in Fig. 1.

\section{White blood cells}

Before ART initiation $10 \%$ of the children had elevated white blood cell counts above $11,000 \mathrm{cell} / \mathrm{mm}^{3}$ compared to $6.2 \%$ after 6 months of ARV initiation. The proportion of children with elevated total WBC thus decreased with ART RR $=0.76[(0.54,1.08) \mathrm{P}=0.09]$ a non-significant decline. Overall the median total WBC count at baseline was $9.4 \times 10^{3} / \mathrm{mm}^{3}$ which declined significantly to a median of $6.7 \times 10^{3}$ cells/ $\mathrm{mm}^{3}$ ( $\left.\mathrm{p}<0.0001\right)$. At baseline only $6.5 \%$ of the study participants had granulocyte counts of less than 1000 cells $/ \mathrm{mm}^{3}$ compared to $16 \%$ after 6 months of ARVs, a statistically significant increased likelihood of having low granulocyte counts $R R=1.48[(1.25,1.75)$, $\mathrm{P}<0.0001]$. The total granulocyte count declined significantly following 6 months of ART from a median of $2.8 \times 10^{3} / \mathrm{mm}^{3}-2 \times 10^{3} / \mathrm{mm}^{3}$ (IQR $1.4 \times 10^{3} / \mathrm{mm}^{3}-$ $\left.5.1 \times 10^{3} / \mathrm{mm}^{3}\right)(\mathrm{p}<0.0001)$ as shown in Table 5 . The median lymphocyte count was of $5.2 \times 10^{3} \mathrm{cell} / \mathrm{mm}^{3}$ before treatment initiation and declined significantly to $4.2 \times 10^{3}$ cell $/ \mathrm{mm}^{3},(\mathrm{p}<0.0001)$ following 6 months of ART.

\section{Factors associated with low baseline hemoglobin level}

In a stratified analysis the 216 (64.1\%) and 121 (35.9\%) children with $\mathrm{Hb}$ above and below $10 \mathrm{~g} / \mathrm{dl}$ respectively were compared to determine demographic and clinical characteristics associated with anemia. Children in WHO stage 3 and 4 were more likely to have $\mathrm{Hb}$ of less than or equal to $10 \mathrm{~g} / \mathrm{dl}$ compared to children in WHO stage 1 and 2 OR $=10.6(95 \%$ CI 3.64, 36.3) $(\mathrm{P}<0.001)$. Children with WAZ greater than -2 SD had significantly reduced likelihood of having $\mathrm{Hb}$ of less than $10 \mathrm{~g} /$ $\mathrm{dl} \mathrm{OR}=0.62[(95 \% \mathrm{CI} 0.38,1.01) \mathrm{P}=0.04]$ as shown in Table 6.

\section{Discussion}

In this study we report increase in most hematological indices following 6 months of ART in children. Following 6 months of treatment with HAART, hematological reconstitution occurred progressively for all blood lineages except RBC, total WBC, granulocytes and total lymphocytes counts. The positive effect of HAART is probably due to the reduction in viral load, decreased destruction of mature hematopoietic cells of multiple lineages and an improvement in the blunted erythropoietin response [11]. HAART could also have lead to decreased incidences of opportunistic infections [17]. 


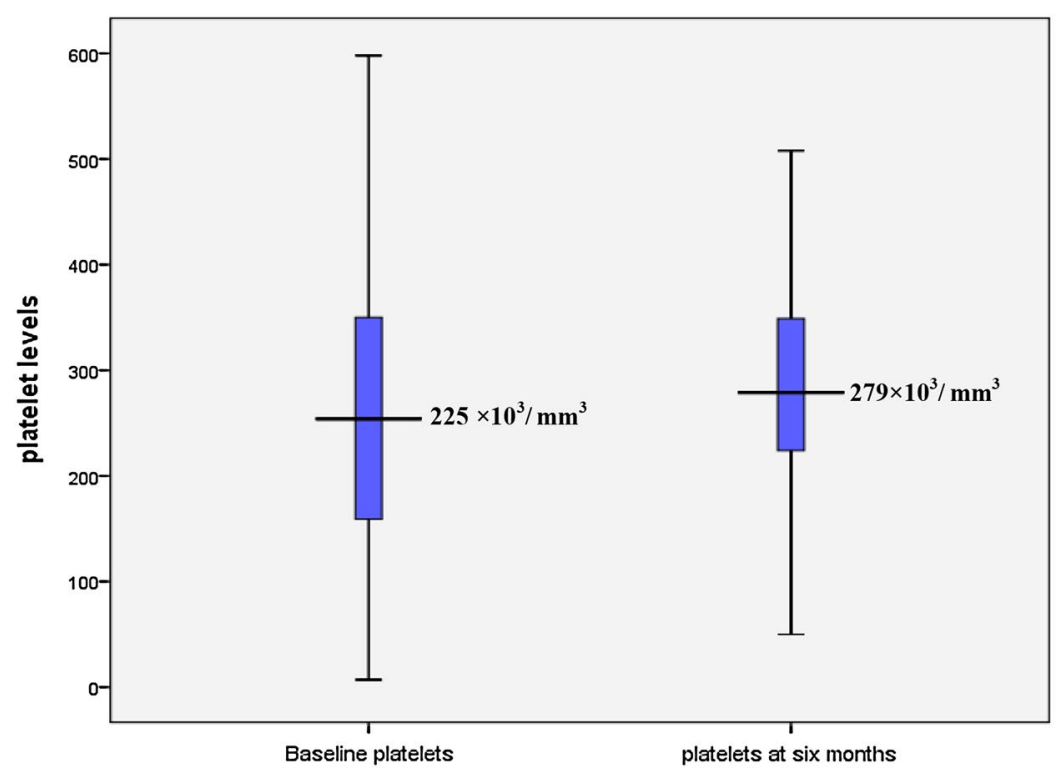

$\mathbf{P}<0.0001$

Fig. 1 Comparison of platelet levels at baseline and after 6 months of treatment

Table 5 Changes in WBC, Granulocytes and lymphocytes following six months of HAART

\begin{tabular}{llllr}
\hline Characteristic $\mathbf{N}=\mathbf{3 3 7}$ & Baseline Median (IQR) & $\begin{array}{l}\mathbf{6} \text { months after of HAART } \\
\text { Median (IQR) }\end{array}$ & Median change & P value \\
\hline WBC $\left(\times 10^{3} / \mathrm{mm}^{3}\right)$ & $8.7(\mathrm{IQR} 6.2-11.5)$ & $6.7(\mathrm{IQR} 5.2-8.5)$ & 2.0 & $<0.0001$ \\
Granulocytes $\times 10^{3} / \mathrm{mm}^{3}$ & $2.8(\mathrm{IQR} 1.8-4.3)$ & $2.0(\mathrm{IQR} 1.4-2.9)$ & 0.8 & $<0.0001$ \\
Lymphocytes $\times 10^{3} / \mathrm{mm}^{3}$ & $4.8(2.9-6.7)$ & $4.2(3.0-5.1)$ & 0.6 & $<0.0001$ \\
\hline
\end{tabular}

Table 6 Correlates of low baseline haemoglobin level

\begin{tabular}{|c|c|c|c|c|}
\hline & $\begin{array}{l}\mathrm{Hb} \geq 10 \\
\mathrm{~N}=216 \\
(64.1 \%)\end{array}$ & $\begin{array}{l}\mathrm{Hb} \leq 10 \\
\mathrm{~N}=121 \\
(35.9 \%)\end{array}$ & & $P$ value \\
\hline CD4 (median) & 9.0 & 10.8 & & 0.2 \\
\hline WHO & & & & $<0.0001$ \\
\hline $\begin{array}{r}\text { Stage } 1 \\
\text { and } 2\end{array}$ & 76 (35.2 \%) & 4 (8.2\%) & 1 & \\
\hline $\begin{array}{r}\text { Stage } 3 \\
\text { and } 4\end{array}$ & 140 (64.8 \%) & $80(81.8 \%)$ & $\begin{array}{c}10.6(3.64 \\
36.3)\end{array}$ & \\
\hline WHZ & & & & 0.58 \\
\hline$<-2$ & 26 (12.0 \%) & 17 (14.2 \%) & 1 & \\
\hline$>-2$ & 190 (88.0 \%) & 103 (85.8 \%) & $\begin{array}{c}0.83(0.41 \\
1.68)\end{array}$ & \\
\hline WAZ & & & & 0.04 \\
\hline$<-2$ & 124 (57.4 \%) & 83 (68.6 \%) & 1 & \\
\hline$>-2$ & 92 (42.6 \%) & 38 (31.4 \%) & $\begin{array}{l}0.62(0.38 \\
1.01)\end{array}$ & \\
\hline
\end{tabular}

The median increase in $\mathrm{Hb}$ levels of $0.9 \mathrm{~g} / \mathrm{dl}$ was well within the range of the $0.8-1.0 \mathrm{~g} / \mathrm{dl}$ in published studies. Microft et al. in Europe and Huang et al. reported an increase from 13.9 to $14.6 \mathrm{~g} / \mathrm{dl}$ a statistical association between the level of $\mathrm{Hb}$ and duration of use of HAART was also found [16, 17]. In children, Bolton-Moore et al. found that for children with baseline mean $\mathrm{Hb}$ of $10.3 \mathrm{~g} /$ $\mathrm{dl}$, it had increased to $11.3 \mathrm{~g} / \mathrm{dl}$ after6 months of HAART almost similar to our study [18]. In another study in Burkina-Faso, Nacoulma et al. found that after 6 months of AZT based HAART anemia prevalence had reduced [19]. Drug regimen was noted to have a big influence on the increments in hemoglobin level with Stavudine combination having a much higher increment as compared to zidovudine combination findings similar to other studies [20].

In this study children who received iron supplements were noted to have higher hemoglobin increments this is similar to the findings in Malawi where iron supplementation in HIV infected children increased hemoglobin levels and reduced the prevalence of anemia by $40 \%$ but iron was noted to increase the risk of malaria [21]. Identification of children to be given iron in this study was based on low baseline hemoglobin levels as recommended by WHO on targeted iron supplementation for children at risk of anemia and iron deficient 
[14]. Children who received these drugs had markedly reduced hemoglobin level at baseline. Some of these children were also provided with food supplement and nutritional education and this could have contributed to marked increase. The study was not able to identify whether those given iron supplements had higher risk of sepsis due to retrospective nature of the study.

When we compared the mean corpuscular volume at baseline of $75.9 \mathrm{fl}$ with that after 6 months of treatment of $89.2 \mathrm{fl}$, we found an increase in median change that was higher than the findings of Huang et al. in adults of $95.5 \mathrm{fl}$ at baseline to $105.5 \mathrm{fl}$ following 6 months of HAART [17]. The increase could have been due to nutritional modification offered, iron supplements or antiretroviral drugs. Macrocytosis was found to have occurred after treatment and this could be attributed to the effect of mainly zidovudine as this has been found in other studies [22]. A striking and discrepant observation was that the circulating $\mathrm{RBC}$ counts decreased significantly following six months of HAART despite increase in hemoglobin levels and mean corpuscular volume. This finding is similar to the findings of Huang et al. and may be associated with defect in the production of erythrocytes from erythroid progenitor cells leading to the generation of fewer but larger cells [17].

Total white blood cells were found to decrease significantly from $8.7 \times 10^{3} \mathrm{~mm}^{3}$ to $6.7 \times 10^{3} \mathrm{~mm}^{3}$ in this study probably because at the time of enrollment, the children might have had intercurrent acute or chronic infections causing leucocytosis and following treatment and initiation of HAART the levels were seen to have decreased and this could have been due to the antiretroviral drugs improving immunity leading to less infections. Similar findings were reported by Nacoulma et al. in adults after six months of AZT based HAART of $2.27 \times 10^{3} \mathrm{~mm}^{3}$ at baseline compared to $1.9 \times 10^{3} \mathrm{~mm}^{3}$ after 6 months of HAART [19]. The finding in this study contrast some studies which reported significant increase in WBC following treatment with Huang et al. reporting a mean increase of $0.8(\mathrm{p}<0.001)$ [17]. In this study, there was a statistical significant increase in platelets levels from $255 \times 10^{3} \mathrm{~mm}^{3}$ to $279 \times 10^{3} \mathrm{~mm}^{3}$ similar to findings by Huang et al. in adults [17].

In this study the first line regimens as recommended by the Ministry of Health of both zidovudine based and Stavudine based were shown to lead to a significant change in hematological parameters similar to the findings in various other studies $[17,18]$. Moyle $G$ et al. in their study also assessed the mean decreased in hemoglobin level comparing various regimens after treatment which we were unable to do due the small number of patients that were started on Stavudine based and protease inhibitor based regimens [4].

\section{Conclusion}

The findings of this study suggest that Antiretroviral drugs lead to a significant change in hematological parameters with a positive change of hemoglobin levels, $\mathrm{MCV}, \mathrm{MCH}$ and platelet and decrease in total WBC, granulocytes lymphocytes and RBC. This indicates that zidovudine based regimens may safely be used even in setting with limited laboratory monitoring.

\section{Methods}

This retrospective cohort study was carried out at Kenyatta National Hospital comprehensive care centre between September and November 2008. Children were enrolled into the study if they were age 5-144 months, confirmed to be HIV positive by rapid tests for those aged over 18 months and PCR DNA for those aged less than 18 months, attending the Kenyatta National Hospital comprehensive care center. They also had to have received the first line ART according to the Kenyan Ministry of Health guidelines without change of treatment for at least six months with available complete medical records and parents/guardians provided informed consent. Standard study tools were used to abstract data from the medical records of enrolled children and included demographic, clinical and laboratory characteristics. The laboratory data had been analyzed by University of Nairobi Paediatric laboratory which undertakes laboratory procedures relating to the comprehensive care clinic. It uses a semi automated hematology analyzer MS4 and is a GCLP certified (Good Clinical Laboratory Practices) with external quality assurance. There is computerized data for all children attending the clinic who are on HAART and it also details of the regimen the children is on and when started. Using ART number in the data base and patients appointment number we were able to identify the patients' files. Files were retrieved as the clients came for review in their monthly clinic that runs daily from Monday to Friday. Pre and 6-month post ART estimates of, absolute CD4, CD4\%, hemoglobin level, total white blood cells count, absolute lymphocyte counts, granulocyte counts, and platelets counts were recorded in an abstract form. In addition information was obtained regarding use of all medications including prophylactic medications, iron supplementation, multivitamins, and HAART regimens. Ethical clearance to conduct the study was obtained from the department of Pediatrics and Child Health and the $\mathrm{KNH}$ ethical review Committee. 


\section{Statistical methods}

Data entry and analysis were done using SPSS version 16.0. The weight for height $Z$ scores (WHZ), height for age $Z$ scores (HAZ) and weight for age $Z$ scores (WAZ) were computed using the nutrition software of Epi Info 3.2 Baseline hematological parameters were compared to those obtained after 6 months of HAART using Pearson Chi square test to compare categorical variables. Wilcoxon paired t-test for non parametric variables was used to determine the difference in baseline hematological parameters and parameters after 6 months of HAART for parameters. Differences in associations and relationships were taken as significant where $\mathrm{P}$ was less than 0.05 .

\begin{abstract}
Abbreviations
HIV: human immunodeficiency virus; HAART: highly active antiretroviral therapy; ARV: anti retroviral therapy; KNH: Kenyatta National Hospital; Hb: hemoglobin level; RR: relative risk; MCV: mean corpuscular volume; $\mathrm{MCH}$ : mean corpuscular hemoglobin; WHO: World Health Organization; WBC: white blood cells; Ol: opportunistic infection; ART: anti retroviral therapy; IDA: iron deficiency anemia; AZT: zidovudine; NVP: nevirapine; EFV: efavirenz; RBC: red blood cells; PCR: polymerase chain reaction; ABC: abacavir; 3TC: Stavudine; GCLP certified: good clinical laboratory practices.
\end{abstract}

\section{Authors' contributions}

All authors conceptualized the study and wrote the proposal. EGK carried out the data collection while RN, DW and NK supervised the work and frequently advised during the study. All authors participated in data analysis and wrote the manuscript. All authors read and approved the final manuscript.

\section{Authors' information}

EGK is a lecturer and a consultant Paediatrician who received her M.B.ch.B degree from Moi University in Kenya in 2001. She later joined University of Nairobi in Kenya for her Masters degree in Paediatric and child health. She has been working in Egerton University for the last 3 years and she is the Founding Chairperson of the Department of Paediatrics in Egerton University. RN is a Professor of Paediatrics at the School of Medicine, College of Health Sciences, University of Nairobi. She is a Paediatrician and Epidemiologist who has taught at the University of Nairobi for many years. Her major achievement is her contribution to the understanding of the epidemiology and biology of breast milk transmission of HIV and in integration of prevention of mother-to-child transmission (PMTCT) of HIV in resource constrained settings.

DW is an associate Professor in the Department of Paediatrics and Child Health, University of Nairobi and a Consultant Paediatrician. He has experience in conducting research studies in Maternal Newborn and Child Health as well as Paediatric HIV. NK has been in practice for 23 years and she holds an M. B. Ch. B and MMed (Paediatrics) from the University of Nairobi. She has formerly worked at Kenyatta National Hospital, Ministry of Health, Hammersmith Hospital London and the University Of Nairobi School Of Medicine.

\section{Author details}

${ }^{1}$ Department of Paediatrics and Child Health, Egerton University, P.O. Box 536-20115, Egerton, Kenya. ${ }^{2}$ Department of Paediatrics and Child Health, University of Nairobi, P. O. Box 19676-00202, Nairobi, Kenya. ${ }^{3}$ Paediatric Hematology and Oncology, University of London, London, UK. ${ }^{4}$ P.O. Box 2275-20100, Nakuru, Kenya.

\section{Acknowledgements}

We wish to express our sincere gratitude to the staffs of Kenyatta National Hospital, Comprehensive Care Centre for their support and assistance in provision of medical records, administration of the hospital and the lecturers in the department of paediatric and child health, University of Nairobi for their guidance, patience, commitment and overwhelming support during the period of research. We also wish to acknowledge the Deputy Vice Chancellor Division of Research and Extension, Egerton University for his continued support and encouragement during the preparation of the manuscript.

\section{Compliance with ethical guidelines}

\section{Competing interests}

The authors declare that they have no competing interests.

Received: 9 December 2014 Accepted: 7 August 2015

Published online: 15 August 2015

\section{References}

1. Spivak JL, Bender BS, Quinn TC (1984) Hematological abnormalities in the acquired immune deficiency syndrome. Am J Med 77:224

2. Ministry of Health, Government of Kenya (2005) Diagnosis and Staging of HIV in children. In: Ibrahim M, Isaiah T, Sylvia O et al. (eds) Guideline for Antiretroviral therapy in Kenya. p 56

3. Mwanda OW (1997) Hematological changes in human immunodeficiency virus infection. East Afr Med J 1:732-739

4. Moore RD (1999) Human immunodeficiency virus infection, anemia, and survival. Clin. Infect. Dis. 29:44-49 (Abstract/FREE Full Text)

5. Consolini R, Benviclli W, Legitimo A, Galli L, Tovo P et al (2007) Pre HAART follow- up study of the hematological manifestation in children with prenatal HIV infection, suggestions for reclassification of clinical disease. Italian register for HIV infection in children. Paediatri. Hematol Oncol 29:376-383

6. Adetifa IM, Temiye EO, Akinsulie AO, Ezeaka VC, Iroha EO (2006) Hematological abnormalities associated with paediatric HIV/AIDS in Lagos. Ann Trop Paediatr 26(2):121-125

7. Totin D, Ndugwa C, Mmiro F et al (2002) Iron deficiency anemia is highly prevalent among HIV infected and uninfected infants in Uganda American Society of nutritional sciences. J Nutri 132:423-429 (PubMed)

8. Eley BS, Sive AA, Shuttleworth M, Hussey GD (2002) Prospective cross sectional study of anemia and iron status in HAART naïve HIV infected children in South Africa. BMC Infect Dis 2:3 (PMC free article, PubMed)

9. Suarez DA, Rao PR, Miller JS (1994) Prevalence of lymphopenia in children with AIDS. Clin Pediatr 33(4):204-208

10. Calis JC, van Hensbroek MB, de Haan RJ, Moons P, Brabian BJ, Bates (2008) HIV-associated anemia in children: systemic review from global perspective. AIDS 22(10):1099-1112 (PubMed)

11. Ellaurie M, Bernstein $L$, Shah K et al (1986) Thrombocytopenia in Paediatrics AIDS. Blood 68:124a

12. Karpatkin S, Nardi MA, Green D (2002) Platelet and coagulation defect associated with HIV infection. Thromb Haemost 88:389-400

13. Foote EM, Sullivan KM, Ruth LJ, Oremo J, Sadumah I, Williams TN, Suchdev PS (2013) Determinants of Anemia among Preschool Children in Rural, Western Kenya. Am J Trop Med Hyg. 88(4):757-764. doi:10.4269/ ajtmh.12-0560

14. WHO (2001) Iron Deficiency Anemia assessment, Prevention, and Control. A guide for programme Managers. http://www.who.int/nutrition/publications/en/ida_assessment_prevention_control.pdf

15. Moyle G, Sawyer W, Law M, Amin J, Hill A (2004) Changes in hematological parameters and efficacy of thymidine analogue based highly active antiretroviral therapy: meta-analysis of six prospective, randomized comparative studies. Clin Ther 26(1):92-97

16. Mocroft A, Kirk O, Barton SE, EuroSIDA Study Group (1999) Anemia is an independent predictive marker for clinical prognosis in HIV infected patients across Europe. AIDS 13:943-950

17. Huang SS, Barbour JD, Deeks SG, Huang SJ, Grant RM et al (2000) Reversal of human immunodeficiency Virus type 1-Associated hematosuppression by effective antiretroviral therapy. Clin Infect Dis 30:504-510

18. Bolton-Moore C, Mubiana-Mbewe M, Cantrell RA, Chintu N, Stringer EM et al (2007) Outcomes and CD4 cell response. Clinical in children receiving Antiretroviral Therapy at Primary health care facilities in Zambia. JAMA 289:1888-1899 
19. Nacoulma EW, Some Y, Tieno H, Diallo I, Zoungrana A et al (2007) Hematological parameters evolving during antiretroviral therapy of HIV infected patients in Bukina-faso. Bull Soc Pathol 100(4):271-274

20. Kiragga AN, Castelnuovo B, Nakanjako D, Manabe YC (2010) Baseline severe anemia should not preclude use of zidovudine in antiretroviraleligible patients in resource-limited settings. J Int AIDS Soc. 13:42. doi:10.1186/1758-2652-13-42 (PMCID: PMC2991285 Published online 2010 Nov 3)
21. Esan MO, van Hensbroek MB, Nkhoma E, Musicha C, White SA, Ter Kuile FO, Phiri KS (2013) Iron supplementation in HIV-infected Malawian children with anemia: a double-blind, randomized, controlled trial. Clin Infect Dis 57(11):1626-1634. doi:10.1093/cid/cit528 (PubMed Abstract Publisher Full Text)

22. Pryce C, Pierre RB, Steel-Duncan J, Evans-Gilbert T, Palmer P, Moore J, Rodriguez B, Christie CD (2008) Safety of antiretroviral drugs in Jamaican children with HIV. West Indian Med J 57(3):238-245

Submit your next manuscript to BioMed Central and take full advantage of:

- Convenient online submission

- Thorough peer review

- No space constraints or color figure charges

- Immediate publication on acceptance

- Inclusion in PubMed, CAS, Scopus and Google Scholar

- Research which is freely available for redistribution

Submit your manuscript at

www.biomedcentral.com/submit

C Biomed Central 